\title{
Ageing societies and the welfare state: where the inter-generational contract is not breached
}

\author{
By Kathrin Komp E Theo van Tilburg
}

The populations in industrialised countries are currently ageing dramatically. Europe is presently the oldest continent and still experiences rapid population ageing (United Nations 2009). The share of Europeans aged 65 years and older is expected to increase from $17 \%$ in 2008 to $30 \%$ in 2060 (Eurostat 2008). Japan, though, has an even older population than the European countries. In 2009, 30\% of the Japanese were aged 60 years and older, while the percentage was only 26 in Germany and Italy, the oldest European countries (United Nations 2009). This demographic shift changes the character of societies. Older persons' needs and possibilities become more visible and the social risks associated with old age become more urgent. Those risks are primarily the ones of poverty and poor health in old age (Bonoli 2005; Walker 2000). Tackling these risks does not only become more important, it might also receive more support since an increasing share of the population is affected by those risks (Busemeyer et al. 2009). Addressing poverty and poor health in old age in ageing societies, however, challenges one of the central concepts in welfare states: the inter-generational contract.

The inter-generational contract is a system of behaviours and expectations that regulates transfers across generations. The basic idea is that social risks are concentrated at the beginning and at the end of the lifecourse (Kabeer 2000). Therefore, if middle-aged individuals were to support the young and the old, then one would be protected during the most vulnerable periods of one's life. In exchange, middle-aged persons can expect support in their own old age (Svallfors 2008). This idea of 
International Journal of Ageing and Later Life

transfers between generations plays a central role in many welfare state arrangements. In practice, however, it is only sustainable if two conditions are fulfilled. First, the demands on middle-aged persons to support young and old persons cannot be excessive. Otherwise, middle-aged persons might use such a big share of their resources on transfers that they themselves enter into a precarious situation. This would turn middle-age into a vulnerable period within the life-course. Second, the size of future generations must not decrease dramatically. Otherwise, middle-aged individuals might not receive sufficient support when they are old, making the participation in the inter-generational contract unattractive to them. Consequently, opposition to the inter-generational contract could arise among young and middle-aged persons (Ginn \& Arber 2000; Svallfors 2008). Ageing populations are assumed to challenge both conditions for the sustainability of the inter-generational contract.

The fear of a breach of the inter-generational contract is most strongly pronounced regarding pay-as-you-go (PAYG) financed pension schemes. Such pension schemes can, for example, be found in Germany and Sweden (Organisation for Economic Co-operation and Development [OECD] 2006; Schmähl 2007). They collect contributions from today's middle-aged persons and distribute them as benefits to today's older persons (Ginn \& Arber 2000; Goldstein 2009). They thus use a simplified version of the inter-generational contract in that they only distribute resources from younger to older generations. Population ageing entails that middle-aged persons contribute more to pension schemes without the prospect of receiving sufficient pension benefits in their old age. Governments try to correct this situation, for example, by delaying retirement and lowering pension benefits (OECD 2006).

Besides PAYG-financed pension schemes, the care provision within families might also suffer from a breached inter-generational contract (Izuhara 2002). Within families, middle-aged persons often provide informal care to children and older persons. Due to population ageing, the demand for informal care for older persons increases while today's middle-aged persons might not receive sufficient care from family members in their own old age (Izuhara 2002; Walker 1996). This challenge to informal care-giving, however, receives less attention than the pressure on PAYG-financed pension schemes. One reason might be that pension 
schemes are located in the public sphere, while informal care-giving occurs in the private sphere. Another reason might be that transfers within pension schemes are codified and distributed in cash, while care-giving within families occurs in kind, without any codification (Attias-Donfut \& Arber 2000; Izuhara 2002; McGregor et al. 2000). Despite not being at the forefront of political discussions, the pressure of ageing populations on the inter-generational contract within families is greatly relevant for welfare states. Middle-aged women, in particular, need to balance paid work against informal care-giving (e.g. Dautzenberg et al. 2000; EspingAndersen 2002). If they cut back on paid work in order to provide informal care, they might not accumulate sufficient pension claims and be at risk of old-age poverty. Governments would, therefore, have to provide more social assistance to women in later life (O'Rand \& Shuey 2007). If, on the other hand, women cut back on informal care-giving in order to work for pay, unmet needs for care might result and governments would need to provide more social-care services (Esping-Andersen 2002; Lima et al. 2008).

While population ageing challenges the inter-generational contract, it does not put a uniform kind of pressure on it. Rather, there are differences in the state of the inter-generational contract, cutting across generations. Gender and socio-economic status, for example, influence which resources a person transfers to other generations and which resources he or she receives (Attias-Donfut \& Arber 2000; Izuhara 2002). This variation in the state of the inter-generational contract is the focus of this special issue of the International Journal of Ageing and Later Life. ${ }^{1}$ The first article in this special issue, written by Kate A. Hamblin, investigates changes in policies facilitating early retirement. It does this by comparing European countries and different kinds of work biographies. In the second article, Kathrin Komp, Theo van Tilburg and Marjolein Broese van Groenou study workforce participation between 60 and 70 years of age. In their analysis,

\footnotetext{
${ }^{1}$ The articles in this special issue are based on contributions to a workshop for PhD students, entitled "Ageing Societies and the Welfare State". The workshop took place on 11-12 December 2008, in Amsterdam, the Netherlands. It was organised in cooperation between the Research Network on Ageing in Europe (European Sociological Association) and the European Network for Social Policy Analysis.
} 
International Journal of Ageing and Later Life

they compare levels of socio-economic status across European countries. The final article, written by Meiko Makita, focuses on informal care-giving. It examines gender differences in informal care-giving within Japanese families. Taken together, the articles in this special issue shed light on the complex influence of population ageing on the inter-generational contract. They underline that this influence cannot be summarised in a single statement, which speaks against portraying population ageing as a mere problem between generations. Instead, a differentiated assessment is necessary, paying attention to differences within generations and between countries.

\section{References}

Attias-Donfut, C. \& Arber, S. (2000). Equity and solidarity across the generations. In S. Arber \& C. Attias-Donfut (eds.), The Myth of Generational Conflict. The Family and State in Ageing Societies (pp. 1-21). London: Routledge.

Bonoli, G. (2005). The politics of the new social policies: Providing coverage against new social risks in mature welfare states. Policy $\mathcal{E}$ Politics 33(3): 431-449.

Busemeyer, M. R., Goerres, A. \& Weschle, S. (2009). Attitudes towards redistributive spending in an era of demographic ageing: The rival pressures from age and income in 14 OECD countries. Journal of European Social Policy 19(3): 195-212.

Dautzenberg, M. G. H., Diederiks, J. P. M., Philipsen, H., Stevens, F. C. J., Tan, F. E. S. \& Vernooij-Dassen, M. J. F. J. (2000). The competing demands of paid work and parent care. Middle-aged daughters providing assistance to elderly parents. Research on Aging 22(2): 165-187.

Esping-Andersen, G. (2002). A new gender contract. In G. EspingAndersen, D. Gallie, A. Hemerijck \& J. Myles (eds.), Why We Need a New Welfare State (pp. 68-95). Oxford: Oxford University Press.

Eurostat (2008). Ageing characterises the demographic perspectives of the European societies. Statistics in Focus - Population and Social Condition 72.

Ginn, J. \& Arber, S. (2000). Gender, the generational contract and pension privatization. In S. Arber \& C. Attias-Donfut (eds.), The Myth of 
Generational Conflict. The Family and State in Ageing Societies (pp. 133153). London: Routledge.

Goldstein, J. R. (2009). How populations age. In P. Uhlenberg (ed.), International Handbook of Population Aging (Vol. 1, pp. 7-18). New York: Springer.

Izuhara, M. (2002). Care and inheritance: Japanese and English perspectives on the 'generational contract'. Ageing \& Society 22(1): 61-77.

Kabeer, N. (2000). Inter-generational contracts, demographic transitions and the 'quantity-quality' tradeoff: Parents, children and investing in the future. Journal of International Development 12: 463-482.

Lima, J. C., Allen, S. M., Goldscheider, F. \& Intrator, O. (2008). Spousal caregiving in late midlife versus older ages: Implications of work and family obligations. The Journals of Gerontology: Social Sciences 63B(4): S229-S238.

McGregor, A. J., Copestake, J. G. \& Wood, G. D. (2000). The intergenerational bargain: An introduction. Journal of International Developelopment 12: 447-451.

O'Rand, A. M. \& Shuey, K. M. (2007). Gender and the devolution of pension risks in the US. Current Sociology 55(2): 287-304.

Organisation for Economic Co-operation and Development (2006). Ageing and Employment Policies: Live Longer, Work Longer. Paris: OECD.

Schmähl, W. (2007). Dismantling an earnings-related social pension scheme: Germany's new pension policy. Journal of Social Policy 36(2): 319-340.

Svallfors, S. (2008). The generational contract in Sweden: Age-specific attitudes to age-related policies. Policy \& Politics 36(3): 381-396.

United Nations (2009). World Population Ageing 2009. New York: United Nations.

Walker, A. (1996). Intergenerational relations and the provision of welfare. In A. Walker (ed.), The New Generational Contract. Intergenerational Relations, Old Age and Welfare (pp. 10-36). London: UCL Press.

Walker, A. (2000). Public policy and the construction of old age in Europe. The Gerontologist 40(3): 304-308. 